Nurvitasari, S., Azizah, L.Z., \& Sunarno, S. (2018). Konsep dan Praktik Pendidikan Inklusi di Sekolah Alam Ramadhani Kediri. Indigenous: Jurnal Ilmiah Psikologi, 3(1), 15-22. doi:https://doi. org/10.23917/indigenous.v3i1.5743

\title{
Konsep dan Praktik Pendidikan Inklusi di Sekolah Alam Ramadhani Kediri
}

\author{
Siti Nurvitasari ${ }^{1}$, Lisa Zakia Azizah ${ }^{2}$,S. Susarno ${ }^{3}$ \\ STAIN Kediri ${ }^{123}$ \\ sitinurvitasariximpii@gmail.com¹ aziza.dzakiy@gmail.com² sunarno.stain@gmail.com ${ }^{3}$
}

\begin{abstract}
Abstraksi. Sekolah Alam biasanya hanya diperuntukkan bagi kalangan menengah keatas dan fokus pada anak normal. Namun berbeda dengan Sekolah Alam Ramadhani Kediri, yang menjadikannya sebagai sekolah inklusi dan untuk kalangan menengah kebawah. Fenomena ini menarik peneliti untuk mengetahui praktik pendidikan inklusi di sekolah tersebut. Metode penelitian yang digunakan adalah kualitatif dengan pendekatan studi kasus. Teknik penggalian data adalah dengan wawancara dan observasi. Hasil penelitian menunjukkan: Sekolah Alam Ramadhani memiliki prinsip memanusiakan manusia, tanpa membedakan antara anak normal dengan anak berkebutuhan khusus (ABK). Pendidikan inklusi di Sekolah Alam Ramadhani berkiblat pada Ki Hajar Dewantara, dan mengadopsi sistem "Among". Dalam praktiknya: anak normal dan berkebutuhan khusus mendapatkan pendampingan dan fasilitas sama, pada keduanya ditanamkan kasih sayang dan toleransi, serta untuk $A B K$, didampingi untuk mengembangkan bakat alami yang dimilikinya. Dengan demikian dapat disimpulkan bahwa Sekolah Alam Ramadhani menerapkan sistem "Among".
\end{abstract}

Kata kunci: Sekolah alam ramadhani, pendidikan inklusi, sistem among

\section{PENDAHULUAN}

Anak, siapa pun dan seperti apa pun kondisinya melekat pada dirinya martabat dan melekat hak-hak asasi kemanusiaan. Hal ini telah disepakai oleh Perserikatan Bangsa-Bangsa dalam Deklarasi Universal tentang Hak-Hak Asasi Manusia, bahwa masa kanak-kanak memerlukan perawatan dan pendampingan secara khusus. Selain itu, anak demi untuk pengembangan dan keharmonisan kepribadiannya, harus tumbuh dalam lingkungan keluarga, dalam iklim kebahagiaan, cinta kasih dan pengertian (Perserikatan Bangsa-Bangsa, 1989).

Pasal 2 dalam Deklarasi Universal tentang Hak-hak Asasi Manusia tersebut menyebutkan bahwa anak tidak boleh dibeda-bedakan. Tidak boleh dibeda-bedakan disini tidak hanya dalam perbedaan fisikal berupa perbedaan agama, suku, ras, jenis kelamin dan budaya, tetapi juga kondisi mentalitas anak. Dilanjutkan pada pasal 3, bahwa hal-hal terbaik menyangkut hidup anak harus menjadi pertimbangan utama (Perserikatan Bangsa-Bangsa, 1989).
Satu diantara hal yang harus menjadi pertimbangan utama hak asasi anak adalah pendidikan. Bahwa Negara harus mengakui hak anak atas pendidikan, yaitu diantara dengan membuat pendidikan yang terbuka bagi semua anak. Terkait hal ini termaktub dalam Deklarasi Universal tentang Hak-hak Asasi Manusia pada Pasal 28 (Perserikatan Bangsa-Bangsa, 1989). Lebih jauh menyoal hak anak atas pendidikan, bahwa pendidikan merupakan hal yang sangat penting dalam meningkatkan kesejahteraan dan penurunan kemiskinan (Unicef Indonesia, 2012).

Terkait ketersediaan pendidikan anak berkebutuhan khusus, di Indonesia telah diatur dalamUndang-undang Republik Indonesia Nomor 20 tahun 2003 tentang sistem pendidikan nasional yang memberikan model lain dalam penyediaan pendidikan bagi anak yang berkebutuhan khusus. Pada pasal 15 dijelaskan bahwa, pendidikan khusus merupakan pendidikan untuk peserta didik yang abnormal atau memiliki kecerdasan luar biasa yang diselenggarakan secara inklusif atau 
berupa satuan pendidikan khusus pada tingkat pendidikan dasar dan menengah (Ilahi, 2013).

Terkait ketersediaan pendidikan anak berkebutuhan khusus, di Indonesia telah diatur dalamUndang-undang Republik Indonesia Nomor 20 tahun 2003 tentang sistem pendidikan nasional yang memberikan model lain dalam penyediaan pendidikan bagi anak yang berkebutuhan khusus. Pada pasal 15 dijelaskan bahwa, pendidikan khusus merupakan pendidikan untuk peserta didik yang abnormal atau memiliki kecerdasan luar biasa yang diselenggarakan secara inklusif atau berupa satuan pendidikan khusus pada tingkat pendidikan dasar dan menengah (Ilahi, 2013).

Pendidikan inklusif diharapkan mampu membuat anak berkebutuhan khusus tidak termarginalkan dan mampu membuat mereka mengembangkan potensinya. Namun penerapan pendidikan inklusif di berbagai sekolah, nyatanya belum semuanya mampu menerapkan model pendidikan inklusif. Kesiapan menerima anak berkebutuhan khusus, yang memiliki karakter spesial dan memerlukan pendampingan memang harus memiliki strategi untuk mampu membantunya agar dapat mengembangkan ketrampilannya (Ilahi, 2013).

Standar pendidikan yang digunakan untuk menghadapi anak berkebutuhan khusus dengan anak normal lainya tentu berbeda, sebab kebutuhan dan tahap perkembangan yang dilalui juga berbeda. Metode yang akan digunakan lebih baik jika mampu menembus pintu kecerdasan masing-masing anak. Karena setiap anak memiliki potensi berbeda yang dibawanya atas pengaruh gen maupun lingkungan, oleh sebab itu pembelajaran kepada anak disesuaikan dengan kemampuannya (Chatib, 2009). Hal ini sejalan dengan penelitian Hidayat tentang "Pembelajaran Pendidikan Agama Islam Pada Kelas Inklusi di SD Islam Terpadu Annida Sokaraja Kabupaten Banyumas Tahun 2013/2014", bahwa pembelajaran PAI pada kelas inklusi di SD IT Annida Sokaraja disesuaikan berdasarkan kemampuan ABK, sehingga komponen-komponen pembelajaran dari tujuan, materi, metode, media, dan evaluasi pembelajaran berbeda dengan kelas reguler (Hidayat, 2015).

Sekolah Alam (inklusif), sebagai bentuk dari salah satu lembaga pendidikan alternatif belum banyak dijumpai di kelembagaan pendidikan. Hal ini karena Sekolah Alam dekat dengan berbagai aktivitas yang lebih banyak dilakukan di alam terbuka. Aktivitas-aktivitasnya banyak dengan berinteraksi bersama alam, hal ini tentunya membutuhkan anak untuk banyak gerak. Menurut Lendonovo (penggagas Sekolah Alam di Indonesia) bahwa Sekolah Alam lebih memfokuskan pada alam untuk kebahagiaan (Isriana, 2017).

Menurut Suhendi dan Murdiana (2012), Sekolah Alam merupakan salah satu jawaban atas perbaikan sistem pendidikan yang seragam dan bertujuan untuk mengembangkan potensi anak sesuai dengan kemampuannya. Hal ini senada dengan pemikiran pendidikan Freire (dalam Suhendi dan Murdiana, 2012) bahwa pendidikan harus terbuka pada pengenalan realitas diri, selain itu pendidikan juga harus mengimplikasikan konsep tentang manusia dan dunianya agar manusia dapat menjadi subjek dari diri sendiri.

Sekolah Alam dalam perkembangan mendapatkan stigma dari masyarakat adalah sekolah yang mahal (terkait dengan berbagai aktivitas pembelajaran keluar yang membutuhkan biaya lebih), homogen dan khusus untuk anak normal. Padahal menurut Lendonovo (dalam Isriana, 2017), Sekolah Alam hadir diperuntukkan bagi siapapun. Bahwa Sekolah Alam dapat dinikmati siapa saja khususnya bagi anak yang berkebutuhan khusus. Hal ini dikarenakan Lendonovo sendiri dulunya juga termasuk anak ADHD (Attention Deficit Hyperactivity Disorder). Berdirinya sekolah alam yang dilakukannya, merupakan ketidakpuasan dengan pendidikan konvensional. Sekolah yang didirikan merupakan representasi dari dirinya mengenai keinginan mendirikan sekolah yang membahagiakan.

Adalah Sekolah Alam Ramadhani (dalam penulisan selanjutnya SAR) di Kediri sebuah lembaga pendidikan yang inklusif, menerima siapa pun yang mendaftar dengan seperti apapun kondisi dan latarbelakangnya. SAR yang beralamatkan di Jl Supiturang Utara 13, Mojoroto, Kota Kediri, berdiri pada tahun 2010 dibawah naungan Yayasan Pendidikan Islam Sahhala, dengan jenjang playgroup 
dan Taman kanak-kanak (TK). Sekolah ini didedikasikan bagi anak yang kondisi ekonomi orang tuanya menengah kebawah dan sebuah pergerakan pendidikan alternatif, bahwa untuk memperbaiki pendidikan anak bukan hanya diberikan kepada anak saja. Tetapi bekerjasama dengan beberapa komponen seperti orang tua dan masyarakat.

SAR memiliki sebuah visi, menjadi Pendidikan Alternatif yang Memerdekakan Jiwa Anak di Kota Kediri. Sedangkan misinya adalah,1) mengembalikan dunia anak secara utuh sesuai dengan fase perkembangan, 2) Alam terkembang sebagai laboratorium pendidikan pembelajaran, 3) metode pengasuhan dan pendidikan berbasis kognitif (ngerti), afeksi (ngrasaI), konatif (nglakoni), 4) menciptakan sebuah proses belajar yang fun dan membahagiakan bagi anak.

Terdapat dua program yang ada di SAR yaitu, sambung rasa dan sahabat ramadhani. Sambung rasa adalah kelas orang tua belajar, dimana orangtua mendapat pemahaman seputar Pendidikan anak, program ini juga merupakan media komunikasi antara orangtua dan sekolah. Sedangkan sahabat ramadhani adalah sebuah pergerakan Pendidikan, bahwa SAR memfasilitasi bagi siapapun untuk bergabung bersama memberikan kontribusi demi perbaikan kualitas Pendidikan anak. Bentuk kontribusi dapat berupa materi atau non materi, serta siap berafiliasi dengan siapapun baik perseorangan maupun komunitas untuk bergerak bersama dalam satu kegiatan. Berdasarkan paparan visi, misi, dan program yang ada di SAR, dapat diketahui bahwa SAR menerima siapapun yang mendaftar dan ingin belajar disana, baik bagi siswa normal maupun berkebutuhan khusus. Oleh karenanya SAR dapat dikatakan sebagai sekolah inklusi.

Konsep pendidikan inklusif merupakan konsep pendidikan yang merepresentasikan keseluruhan aspek yang berkaitan dengan keterbukaan dalam menerima anak berkebutuhan khusus untuk memperoleh hak dasar mereka sebagai warga negara. Pendidikan inklusif didefinisikan sebagai sebuah konsep yang menampung semua anak yang berkebutuhan khusus ataupun anak yang memiliki kesulitan membaca dan menulis (Ilahi,
2013). Penyederhanaannya, inklusi merupakan penyatuan bagi anak-anak berkelainan ke dalam program-program sekolah, di kelas-kelas reguler.

Menurut Greenspan, 1997 (dalam Smith et al, 2002), model pembelajaran peserta didik berkebutuhan khusus, yang dipersiapkan oleh para guru di sekolah, ditujukan agar peserta didik mampu untuk berinteraksi terhadap lingkungan sosial. Pembelajaran tersebut disusun secara khusus melalui penggalian kemampuan diri peserta didik yang paling dominan dan didasarkan pada Kurikulum Berbasis Kompetensi sesuai dengan "Gerakan Peningkatan Mutu Pendidikan", yang telah dicanangkan oleh menteri pendidikan nasional tanggal 2 Mei 20012. Kompetensi ini terdiri atas 4 ranah yang perlu diukur meliputi kompetensi fisik, kompetensi afektif, kompetensi seharihari, dan kompetensi akademik (Bandi, 2006).

Fenomena SAR yang inklusif dan didedikasikan untuk masyarakat menengahkebawah tersebut merupakan central phenomenon dalam penelitian yang menarik peneliti untuk melakukan penelitian. Maka dengan penelitian ini penulis ingin menemukan jawaban dari pertanyaan seperti apa konsep pendidikan inklusi SAR dan bagaimana penerapan dari konsep tersebut dalam praktik pendidikan sehari-hari di SAR?

Tujuan penelitian ini, yang pertama untuk mengetahui konsep pendidikan inklusi yang ada di SAR. Kedua, seperti apa penerapan dari konsep pendidikan inklusi tersebut. Adapun hasil dari penelitian ini diharapkan dapat memberikan sumbangan konseptual sekaligus praktis terkait penerapan pendidikan inklusi di Indonesia. Bahwa Sekolah Alam dapat menjadi alternatif pengembangan pendidikan inklusi, temuan maupun konsep yang diterapkan, dan diharapkan dapat dijadikan alternatif acuannya.

\section{METODE PENELITIAN}

Metode penelitian yang digunakan adalah kualitatif dengan pendekatan studi kasus. Model studi kasus adalah memfokuskan penelitiannya pada kasus tertentu, yang menekankan eksplorasi dengan penggalian data secara mendalam (Herdiansyah, 2010). Tipe penelitian yang digunakan adalah studi kasus instrumental 
tunggal, dimana peneliti memfokuskan pada sebuah permasalahan, kemudian memilih satu kasus terbatas untuk menjelaskan persoalan tersebut (Creswell, 1998). Penelitian ini difokuskan pada konsep dan praktik pendidikan inklusi di SAR Kediri dengan subjek penelitian terdiri dari Kepala SAR, 1 guru pendamping anak berkebutuhan khusus, dan 3 orangtua dari anak berkebutuhan khusus. Metode pengumpulan data yang digunakan adalah observasi dan wawancara terstruktur. Adapun analisis data yang digunakan adalah dengan analisis tema, yaitu memfokuskan pada masalah penting dalam memahami kompleksitas kasus (Creswell, 1998).

\section{HASIL DAN PEMBAHASAN}

Berdasarkan hasil penelitian dan wawancara kepada subjek, peneliti membagi menjadi dua temuan besar yaitu konsep pendidikan inklusi di SAR, penerapan konsep tersebut dalam kehidupan sehari-hari di sekolah, dan temuantemuan pada orangtua meliputi motivasi dan kepuasan orangtua dengan praktik pendidikan inklusi di SAR.

Pertama, SAR menerapkan pendidikan inklusi dengan sistem among $\mathrm{Ki}$ Hadjar Dewantara. Sistem among merupakan sistem pendidikan yang berjiwa kekeluargaan dan berhubungan dengan kodrat alam yaitu sebagai syarat untuk mencapai kemajuan secara cepat dan baik. Selain itu juga berhubungan dengan kemerdekaan, sebagai syarat untuk menghidupkan dan menggerakkan anak, baik secara lahir maupun batin, agar memiliki pribadi yang tangguh serta dapat berfikir dan bertindak merdeka (Hariyadi, 1989).

Sistem among di SAR dimaknai sebagai sebuahparadigma dalam melihat anak, bahwa anak adalah manusia yang memiliki rasa, sehingga harus dihormati. Prinsip SAR adalah memanusiakan manusia, tanpa membedakan. Maka, Menurut subjek UY selaku penggagas sekaliguspendiriSAR, anak yang ingin mendaftar di SAR akan diterima dan tidak dibedakan, yang penting manusia. Sehingga anak berkebutuhan khusus, siapapun dan dari kalangan manapun juga boleh mendaftar.
Tidak ada istilah guru dan murid bahwa guru selalu benar, namun disana lebih disebut dengan pamong yang mendampingi anak. Bahkan tidak hanya murid yang belajar pada guru, tapi juga sebaliknya, guru juga banyak belajar dari murid.

Kedua, penerapan sistem among dalam mendidik anak-anak berkebutuhan khusus di SAR, bahwa guru pendamping sebagaiPamong yang bertugas tidak hanya memberi pengetahuan tetapi juga mengajarkan pada anak didik untuk mencari pengetahuannya sendiri. Ketika anak bosan belajar di kelas dan ingin bermain, pamong membebaskan namun tetap mendampinginya diluar kelas.

Menghormati dan memerdekakan jiwa anak adalah kunci guru pendamping dalam mendampingi anak-anak. Memerdekakan disini berarti anak-anak tidak boleh kehilangan dunia bermainnya. Maka, jika orang tua atau guru lain pada umumya melarang anaknya bermain di tempat kotor, jutru SAR membiarkannya. Apa yang dipahami para pendamping adalah, yang di inginkan anak tersebut adalah apa yang belum pernah dia rasakan. Maka anak tersebut dibebaskan merasakan, sebab dari merasakan itulah anak belajar. Pendamping paham betul bahwa keinginan yang ditahan hanya menimbulkan pemberontakan, dan memungkinkan adanya perilaku negatif yang tak diinginkan di kemudian hari. Jadi, ABK dimerdekakakan, tapi tetap dalam lingkup pendampingan.

Hal ini memiliki relevansi dengan asas Taman siswa 1922ketujuh yaitu, ketidakterikatan antara lahir dan batin dengan segenap kesucian hati, maka dalam mendidik anak diniatkan untuk mendekati anak dengan tidak meminta suatu hak, namun menyerahkan diri untuk berhamba kepada anak didik (Gunawan, 1989). Prinsip memerdekakan anak yang dipegang SAR tersebut berangkat dari keresahan dalam dunia pendidikan, diantaranya menyempitnya ruang gerak anak sebagaimana dibuktikan atas pembelajaran dengan model indoor. Sehingga berlawanan dengan tahap perkembangan anak, dimana anak pada usia 0-5 tahun merupakan usia bermain (Hurlock, 1980) 
Konsep mengenai sistem among juga tidak terlepas dari tri pusat pendidikan yaitu, alam keluarga, alam perguruan, dan alam pemuda (Ki Hadjar Dewantara, 2004). Dalam penerapannya, guru di SAR tidak hanya mendampingi anak bermain, tapi juga menyelipkan pengetahuan dalam permainan. Mengenai alam keluarga, SAR mengajak orang tua untuk bekerja sama atas perkembangan anaknya. Kerja sama dilakukan dengan menerapkan sistem yang sama antara di sekolah dan rumah, sehingga tidak terjadi kebingungan penerimaan norma. Bahkan tak jarang, bentuk penanganan ABK di sekolah merupakan hasil dari belajarnya guru kepada orangtua ABK sendiri. Sedangkan alam pemuda, pembelajaran yang ada di SAR lebih banyak dilakukan diluar kelas dan berinteraksi dengan alam, yang merupakan alam asli dan dibutuhkan anak.

Sedangkan konsep memanusiakan manusia di SAR dipraktikkan dengan cara, anak berkebutuhan khusus mendapatkan pendampingan, penjagaan, fasilitas, juga kelas yang sama dengan anak normal. Pendampingan dilakukan dengan penuh perhatian dan penanaman empati. Terdapat kasih sayang dan toleransi yang diterapkan oleh pamomong terhadap anak normal maupun yang berkebutuhan khusus. Kemudian, anak berkebutuhan khusus yang telah diketahui bakat istimewa akan didampingi dan didorong untuk mengembangkan bakat tersebut. Konsep memberikan contoh yang baik, memberi semangat dan mendukung bakat anak-anak ini sebenarnya juga selaras dengan konsep ing ngarsa sung tuladha, ing madya mangun karsa, tut wuri handayani.

Menurut paparan EM, selama enam tahun mengabdi, hingga saat ini sudah ada lima anak berkebutuhan khusus (ABK) yang pernah dan sedang bersekolah di SAR. Anak-anak tersebut meliputi anak autis, hyperaktif, dan anak-anak yang mengalami keterlambatan bicara (speed delay). Keterlambatan bicara yang dimaksud juga bermacam-macam bentuknya, ada yang bicaranya tidak jelas, juga ada yang memang tidak mau bicara sama sekali. Keterlambatan bicara ini, selain disebabkan oleh ke-abnormal- an bawaan atau kerusakan syaraf verbal ketika masa bayi, juga terjadi dan diperparah dengan kurangnya rangsangan.

ABK bernama AL.B merupakan anak autis dan berumur 6 tahun. Anak tersebut anti sosial dan kurang dalam hal berbicara. Penanganannya yaitu,di sekolah, pendamping rajin mengajak anak berkomunikasi. Selain itu,mengembangkan bakat anak yang telah terlihat, yakni menggambar. Melalui gambar anak juga berlatih berkomunikasi, karena pendamping mengajak anak untuk menafsirkan apa yang dia gambar.

ABK bernama $\mathrm{BN}$, merupakan anak yang mengalami keterlambatan bicara (speed delay). Keterlambatan bicara ini mengarah ke tantrum (marah), yang merupakan bentuk agresi karena keinginan yang tidak terpenuhi oleh sebab ketidakpahaman orang lain akan apa yang dia bicarakan. Penanganannya, BN diajak membaur dengan anak yang banyak bicara. Kemudian BN tidak diajarkan untuk menyambung suku kata seperti yang para orangtua ajarkan kepada anaknya, tapi diajarkan satu kata-kata utuh. Misalnya gelas, bukan ge-las. Untuk media pembelajaran yang digunakan dengan kondisinya yang hyperactive adalah gadget, karena BN lebih akrab dengan gadget. Dari situ, EM mengajarkan membaca lewat keyboard di HP nya.

ABK bernama AF, merupakan anak yang mengalami kesulitan bicara dan IQ rendah. AF cenderung pendiam dan suka menyendiri. Maka pendamping mendayagunakan teman-temannya untuk semangat mengajaknya bermain. Selain itu, pembelajarannya tetap disesuaikan dengan kemampuan. ABK selanjutnya adalah siswa playgroup yang bernama AL.K yang mengalami hyperactive dan terlambat bicara. Interaksi dengan teman-temannya juga menjadi penangananan utama bagi $A B K$ dengan kategori tersebut.

ABK bernama RZ, merupakan anak dengan kategori Hyperaktif. Penanganannya, ketika anak tersebut terus bergerak, berlari kesanakemari, pendamping tidak melarang. Kemudian sebagai respon dari keingintahuan RZ yang besar, maka ketika RZ melakukan sesuatu yang 
kreatif, pendamping membiarkan dulu, baru kemudian ditanya, dievaluasi, bahkan diberi reward jika itu positif.

Dari berbagai kategori ABK yang telah dijelaskan, bentuk umum dari penanganan yang dilakukan adalah melatih bicara dan penanaman empati. Selain pendamping intens mengajak komunikasi, latihan bicara dilakukan dengan menyandingkan $\mathrm{ABK}$ dengan anak normal yang pandai dan banyak bicara. Anak juga sering diajak mendengarkan adzan juga khutbah di masjid yang berada dekat dengan sekolah alam. $\mathrm{Hal}$ ini bertujuan untuk memberi rangsangan bicara, juga menambah kosakata $\mathrm{ABK}$ agar lancar berbicara.

Sedang empati ditanamkan pada, baik $\mathrm{ABK}$ maupun anak normal. Untuk $\mathrm{ABK}$, pendamping memahamkan mereka tentang hukum "sebab-akibat". Ketika ABK melakukan kesalahan dan menyakiti teman-temannya, ABK diajarkan untuk senantiasa meminta maaf. ABK disuruh memperhatikan temannya yang menangis sebab ulahnya. Adakalanya ABK juga meneriman balasan dari pendamping, berupa apa yang juga telah $\mathrm{ABK}$ lakukan kepada temannya. Maka setelah muncul rasa empati dan ABK sadar atas apa yang telah dia perbuat, ABK tersebut baru mau meminta maaf atas keinginannya sendiri. Hal ini sekaligus melatih ABK untuk bertanggung jawab.

Untuk anak normal, pendamping menanamkan pengertian bahwa ABK adalah saudara, bahwa ABK tersebut umurnya masih kecil sebab belum bisa bicara dengan lancar. Dari sini pendamping memberi pengertian bahwa ABK memerlukan bantuan dan bimbingan mereka. Hasilnya, mereka mau merangkul, dan mau mengajaknya bermain. Dengan ini ABK pun merasa dihargai, merasa diterima. ABK merasa bukan seorang yang berbeda, merasa sama dengan anak lain. Dan sebenarnya, inilah modal penting pengkondisian dan penanganan ABK tersebut.

Terkait dengan motivasi orangtua ABK menyekolahkan anaknya di SAR dan tingkat kepuasannya, peneliti menemukan bahwa motivasi orangtua ABK memasukkan anaknya di SAR diantaranya adalah (1) tempat yang luas dan jauh dari keramaian (jalan raya), lingkungan yang menyenangkan, (2) mempraktikkan sebuah sistem yang tidak sama dengan lembaga pendidikan konvensional (penyeragaman), (3) anjuran terapis untuk ke sekolah alam,dan SAR adalah yang dirasa paling cocok dengan kebutuhan anaknya, (4) para pendamping SAR yang telaten dan tulus, (5) SAR yang menggunakan konsep kemerdekaan anak.

Terkait tingkat kepuasan orangtua, (1) para orangtua $\mathrm{ABK}$ merasakan puas dengan komunikasi intens dengan guru pendamping terkait perkembangan anaknya. Bahkan, saling sharing juga dilakukan antar orangtua dari ABK meskipun lintas generasi. (2) kepuasan orangtua disebabkan adanya perkembangan signifikan pada diri anak. Beberapa contoh perubahan, misalkan, ada anak yang sejak berhenti menjalani terapis yang awalnya hanya mampu bicara menyebut kata sebanyak hitungan jari, setelah di SAR mulai lancar bicara. Anak yang awalnya suka marah (ngamuk) setelah di SAR perlahan memiliki rasa empati, bahkan sangat sayang kepada adiknya. Mau berbagi mainan dengan teman-temannya, juga menjadi penyayang binatang, (3) puas disebabkan kenyamanan anak di SAR. Bahwa si anak merasa nyaman dan tidak mau diajak pulang sejak pertemuan pertama di SAR, (4) puas karena anak lebih mandiri, dan memiliki banyak teman, (5) puas dengan metode pengasuhan kolaboratif antara guru pendamping SAR dengan orangtua, 6) puas dengan hal-hal kecil yang merubah kebisaan, misalnya, ABK jadi lebih suka makanan buatan mamanya sendiri, daripada jajanan di luar. Anak juga lebih berani mengaktualisasikan dirinya dihadapan orang banyak.

Dari hasil tersebut, SAR memiliki konsep pendidikan inklusi yang berbasis sistem among Ki Hadjar Dewantara dengan menjadikan alam sebagai ruang belajar anakanak yang berkebutuhan khusus. Konsep ini juga sejalan dengan pendapat Suhendi dan Murdiani (2012), bahwa sekolah alam merupakan konsep sekolah yang totalitas dalam pendidikannya. Dimulai dari ranah kecerdasan kognisi, kecerdasan fisik, dan kecerdasan emosi. Selain itu tetap menjadikan alam sebagai sentral pusat dalam pendidikan. 


\section{SIMPULAN}

Berdasarkan hasil penelitian dapat disimpulkan bahwa Praktik Pendidikan Inklusi di SAR menerapkan sistem among Ki Hadjar Dewantara. Dalam praktiknya, ABK dan anak normal berada dalam kelas yang sama. Pendampingan dilakukan dengan penuh perhatian, kasih sayang, toleransi, dan penanaman empati. Anak berkebutuhan khusus yang telah diketahui bakat spesialnya akan didampingi dan didorong untuk mengembangkan bakat tersebut.

Dengan metode-metode yang diterapkan SAR untuk menangani berbagai macam anak berkebutuhan khusus (ABK), diketahui bahwa hasil yang terjadi terbilang signifikan. Terdapat banyak perubahan positif atas perilaku ABK yang awalnya sulit dikendalikan. Masing-masing orangtua juga merasa puas dan bersyukur atas perkembangan yang terjadi pada anak-anaknya. Jadi, SAR dengan sistem among, berhasil menjadikan sekolahnya sebagai sekolah yang cocok untuk pendidikan inklusi. Pendidikan inklusi yang diterapkan di SAR merupakan salah satu terapi untuk menangani ABK dimana anak-anak normal dan guru sebagai masyarakat sosial secara tidak langsung sebagai terapis bagi penyembuhan $\mathrm{ABK}$.

BagiPemerintah, Sistem Among merupakan pemikiran orang asli Indonesia yang dapat diterapkan sepanjang zaman. Hal ini seharusnya menjadi sistem unggulan yang diterapkan dalam sekolah. Bagi Peneliti selanjutnya, diharapkan menambah penelitian baru terkait sistem Among, sehingga menjadi alternatif solusi bagi permasalahan-permasalahan pendidikan yang ada.

\section{DAFTAR PUSTAKA}

Chatib, Munif. (2009). Sekolahnya Manusia. Bandung: Mizan Pustaka.

Creswell, John W. (1998). Qualitative inquiry and research desighn: Choosing among five traditions. New York: SAGE Publication, Inc.

Delphie, Bandi. (2006). Pembelajaran Anak Berkebutuhan Khusus dalam Setting Pendidikan Inklusi. Bandung: Refika Aditama.

Dewantara, Ki Hadjar.(2004). Karya Ki Hadjar Dewantara. Yogyakarta: Majlis Luhur Persatuan Taman Siswa.

Gunawan, Ki. (1989). "Aktualisasi Konsepsi Pendidikan Ki Hadjar Dewantara Dalam Sistem Pendidikan Nasional Indonesia di Gerbang Abad XXI" dalam Ki Hadjar Dewantara Dalam Pandangan Para Cantrik dan Mentriknya. Yogyakarta: Majelis Luhur Persatuan Tamansiswa.

Hariyadi, Ki. (1989). "Ki Hadjar Dewantara Sebagai Pendidik Budayawan, Pemimpin Rakyat" dalam Ki Hadjar Dewantara Dalam Pandangan Para Cantrik dan Mentriknya. Yogyakarta: Majelis Luhur Persatuan Tamansiswa.

Herdiansyah, Haris. (2012). Metodologi Penelitian Kualitatif Untuk Ilmu-Ilmu Sosial. Jakarta: Salemba Humanika.

Hidayat, Khoirudin. (2015). Pembelajaran Penddidikan Agama Islam Pada Kelas Inklusi Di SD Islam Terpadu Annida Sokaraja Kabupaten Banyumas Tahun 2014/2015. Skripsi. Tidak di publikasikan. http://repository.iainpurwokerto.ac.id/213/1/Cover\%2C\%20 BabI\%2CV\%2CDaftar\%20Pustaka.pdf diakses pada 31 Agustus 2017.

Hurlock, Elizabeth B. (1980). A Life-SpanApproach, Fifth Edition. US: McGraw. Hill. Inc.

Ilahi, Mohammad Takdir. (2013). Pendidikan Inklusif. Yogyakarta: Ar-ruzz Media.

Isriana. (2017). Kisah Menarik Lendonovo Sang Penggagas SekolahAlam Indonesia. Dalam http:// www.sumber.com/bola/berita-terkini-bola/sumber/kisah-menarik-lendo-novo,-sangpenggagas-sekolah-alam-indonesia.html diakses pada 31 agustus 2017. 
PerserikatanBangsa-Bangsa. (1989). Konvensi Hak-hak Anak. Dalam https://www.unicef.org/ magic/media/documents/CRC_bahasa_indonesia_version.pdf diaksespada2 Agustus 2017.

Smith, J. David. (2012). Sekolah Inklusif. (Denis, Ny. Enrica, Trans). Bandung: Nuansa.

Suhendi dan Murdiani. (2012). Belajar Bersama Alam. Bogor: SoU Publisher. Unicef Indonesia. (2012). Pendidikan\&Perkembangan Anak Usia Dini. Dalam https://www.unicef.org/ indonesia/id/A3_-_B_Ringkasan_Kajian_Pendidikan.pdf. Diakses pada2 Agustus 2017. 